\title{
Phase equilibria in the quasi-ternary system $\mathrm{HgSe}-\mathrm{Ga}_{2} \mathrm{Se}_{3}-\mathrm{Bi}_{2} \mathrm{Se}_{3}$
}

\author{
Oleg PARASYUK ${ }^{1 *}$, Larysa MARUSHKO ${ }^{2}$, Bogdan ZHDANYUK ${ }^{3}$, Yurii KOGUT $^{1}$ \\ ${ }^{1}$ Department of General and Inorganic Chemistry, Lesya Ukrainka Eastern European National University, \\ Voli Ave. 13, 43009 Lutsk, Ukraine \\ ${ }^{2}$ Department of Organic and Bioorganic Chemistry, Lesya Ukrainka Eastern European National University, \\ Voli Ave. 13, 43009 Lutsk, Ukraine \\ ${ }^{3}$ Department of Ecology and Environment Protection, Lesya Ukrainka Eastern European National University, \\ Voli Ave. 13, 43009 Lutsk, Ukraine \\ * Corresponding author.Tel.: +380-332-249972; e-mail: parasyuk.oleg@eenu.edu.ua
}

Received December 16, 2017; accepted December 27, 2017; available on-line April 1, 2018

The phase equilibria in the quasi-ternary system $\mathrm{HgSe}-\mathrm{Ga}_{2} \mathrm{Se}_{3}-\mathrm{Bi}_{2} \mathrm{Se}_{3}$ were investigated by differential thermal analysis and X-ray diffraction. No quaternary phases were found in the system. The isothermal section of the system at $670 \mathrm{~K}$, part of the section at $520 \mathrm{~K}$, and the liquidus surface projection were constructed. The nature and temperature of the mono- and invariant processes were established.

\section{Semiconductors / Liquid-solid reaction / Phase diagrams / Thermal analysis / X-ray diffraction}

\section{Introduction}

In recent years considerable attention has been paid to the growth of nonlinear optical crystals for IR and laser technology. Obtaining optical-quality crystals of most of the chalcogenides suitable for this purpose requires relatively complex technology, which greatly affects the economic performance of the working elements and devices made from these crystals.

Compounds with defective chalcopyrite structure are promising materials for semiconductor technology. For instance, their use as nonlinear optical materials $\left(\mathrm{HgGa}_{2} \mathrm{~S}_{4}\right.$ and $\left.\mathrm{Cd}_{1-x} \mathrm{Hg}_{x} \mathrm{Ga}_{2} \mathrm{~S}_{4}\right)$ and photosensitive materials $\left(\mathrm{ZnGa}_{2} \mathrm{Se}_{4}\right)$, narrow band optical filters $\left(\mathrm{CdGa}_{2} \mathrm{~S}_{4}\right)$, etc. is known [1-4]. Important characteristics of the compounds of this group are their low sensitivity to impurities and high resistance to ionizing radiation [4]. The $\mathrm{HgGa}_{2} \mathrm{Se}_{4}$ compound has similar properties [3,5-8]. In particular, it is promising as an optical [3] and nonlinear optical material for parametric light generation [1]. One of the main requirements for such materials is the high optical quality of crystals of suitable dimensions. However, information on the properties of $\mathrm{HgGa}_{2} \mathrm{Se}_{4}$ is rather scarce, and the application is limited by technological difficulties to obtain industrial-size crystals. $\mathrm{HgGa}_{2} \mathrm{Se}_{4}$ melts incongruently and has a high-temperature phase transition, which complicates the growth of single crystals of sufficient size. In most cases, the growth of single crystals is performed by chemical vapor deposition (CVD) using iodine as transport agent, although there are several reports on the production of single crystals by melt methods. One of the most common methods used in such cases is the growth of crystals from non-stoichiometric melts. However, there is a problem of solvent selection. We have previously tested $\mathrm{GeSe}_{2}$ and $\mathrm{SnSe}_{2}$ for this purpose [9-11]. The phase diagrams include a field of primary crystallization of $\mathrm{LT}-\mathrm{HgGa}_{2} \mathrm{Se}_{4}$. However, these solvents have a number of disadvantages, including high cost (in the case of $\mathrm{GeSe}_{2}$ ) and the formation of solid solutions of several mol.\% extent. The high value of the ionic radius of $\mathrm{Bi}^{3+}$ may be the cause of the virtually absent solid solubility based on $\mathrm{HgGa}_{2} \mathrm{Se}_{4}$. No liquidus curve belonging to $\mathrm{HgGa}_{2} \mathrm{Se}_{4}$ is expected in the $\mathrm{HgGa}_{2} \mathrm{Se}_{4}-\mathrm{Bi}_{2} \mathrm{Se}_{3}$ system, due to the incongruent melting of the ternary phase. Such formation is more probable in the more complex system $\mathrm{HgSe}-\mathrm{Ga}_{2} \mathrm{Se}_{3}-\mathrm{Bi}_{2} \mathrm{Se}_{3}$ with its ternary eutectics, which should, additionally, lower the temperature of crystallization of the alloys. Based on the phase diagram of the $\mathrm{Ga}_{2} \mathrm{Se}_{3}-\mathrm{Bi}_{2} \mathrm{Se}_{3}$ system, such temperature decrease is likely.

Here we present the results of an investigation of the quasi-ternary system $\mathrm{HgSe}-\mathrm{Ga}_{2} \mathrm{Se}_{3}-\mathrm{Bi}_{2} \mathrm{Se}_{3}$ to determine the most suitable region of the alloys that may be used to obtain $\mathrm{HgGa}_{2} \mathrm{Se}_{4}$ single crystals by the solution-melt method.

The quasi-binary system $\mathrm{HgSe}-\mathrm{Ga}_{2} \mathrm{Se}_{3}$ system was already studied in $[12,13]$. The phase diagram of the system is of the peritectic type. The system features a ternary compound, $\mathrm{HgGa}_{2} \mathrm{Se}_{4}$, which forms in a peritectic reaction, $\mathrm{L}+\mathrm{Ga}_{2} \mathrm{Se}_{3} \leftrightarrows \mathrm{HT}-\mathrm{HgGa}_{2} \mathrm{Se}_{4}$ (peritectic point coordinates $46 \mathrm{~mol} \% \quad \mathrm{Ga}_{2} \mathrm{Se}_{3}$, 
$1143 \mathrm{~K})$. The homogeneity region of this compound is narrow and shifted towards $\mathrm{Ga}_{2} \mathrm{Se}_{3} \quad(50-52$ mol.\% $\mathrm{Ga}_{2} \mathrm{Se}_{3}$ at $\left.470 \mathrm{~K}\right)$. The compound $\mathrm{HgGa}_{2} \mathrm{Se}_{4}$ has a polymorphous transition that takes place in the range 933-913 K. The decrease of the transition temperature corresponds to an increase of the $\mathrm{Ga}_{2} \mathrm{Se}_{3}$ content. $\mathrm{LT}-\mathrm{HgGa}_{2} \mathrm{Se}_{4}$ has a tetragonal thiogallate structure (space group $I-4$ ) with the lattice periods $a=0.5703$, $c=1.076 \mathrm{~nm}$ [14], or $a=0.5693, c=1.0826 \mathrm{~nm} \mathrm{[15].}$ $\mathrm{HT}-\mathrm{HgGa}_{2} \mathrm{Se}_{4}$ is a disordered form of $\mathrm{LT}-\mathrm{HgGa}_{2} \mathrm{Se}_{4}$, and the transition $\mathrm{LT}-\mathrm{HgGa}_{2} \mathrm{Se}_{4} \leftrightarrows \mathrm{HT}-\mathrm{HgGa}_{2} \mathrm{Se}_{4}$ is accompanied by a significant increase of the unit cell volume.

$\mathrm{HgSe}$ forms a solid solution range with disordered sphalerite structure that crystallizes in a narrow temperature range with a minimum at $1058 \mathrm{~K}$ and $8 \mathrm{~mol} . \% \mathrm{Ga}_{2} \mathrm{Se}_{3}$. The solid solution in the range 20-27 mol.\% $\mathrm{Ga}_{2} \mathrm{Se}_{3}$ forms in a peritectic reaction, $\mathrm{L}+\mathrm{HT}-\mathrm{HgGa}_{2} \mathrm{Se}_{4} \leftrightarrows \mathrm{HgSe}$ at $1093 \mathrm{~K}$. The solid solubility decreases with decreasing temperature and does not exceed $10 \mathrm{~mol} \% \mathrm{Ga}_{2} \mathrm{Se}_{3}$ at $470 \mathrm{~K}$.

Solid-state ordering ( $\alpha^{\prime}$ phase) takes place in the concentration range $12-18$ mol. $\% \mathrm{Ga}_{2} \mathrm{Se}_{3}$. Maximum ordering corresponds to the composition $\mathrm{Hg}_{5} \mathrm{Ga}_{2} \mathrm{Se}_{8}$. The diffraction pattern of the corresponding alloy was indexed in $[12,13]$ as an $f c c$ lattice with a doubled edge compared to the sphalerite lattice of the solid solution range of $\mathrm{HgSe}$ ( $\alpha$ phase). The $\alpha^{\prime}$ phase undergoes a solid-state peritectoid decomposition $\alpha^{\prime} \leftrightarrows \alpha+\mathrm{LT}-\mathrm{HgGa}_{2} \mathrm{Se}_{4}$ at $639 \mathrm{~K}$. The crystal structure of $\mathrm{Hg}_{5} \mathrm{Ga}_{2} \mathrm{Se}_{8}$ was investigated by X-ray powder diffraction in [16]. It was found that the ternary phase crystallizes in the cubic space group $F-43 m$ with the period $a=1.16876 \mathrm{~nm}$.

Solid solutions of $\mathrm{Ga}_{2} \mathrm{Se}_{3}$ exist in the range 75-100 mol.\% $\mathrm{Ga}_{2} \mathrm{Se}_{3}$ and have defect disordered sphalerite structure. The boundaries of the solid solutions do virtually not vary with temperature.

The $\mathrm{Ga}_{2} \mathrm{Se}_{3}-\mathrm{Bi}_{2} \mathrm{Se}_{3}$ system was investigated in [17-19]. This is a quasi-binary system of the eutectic type. The system liquidus consists of the curves of primary crystallization of $\mathrm{Ga}_{2} \mathrm{Se}_{3}$ and $\mathrm{Bi}_{2} \mathrm{Se}_{3}$. The coordinates of the eutectic point differ slightly between different authors: $60 \mathrm{~mol} . \% \quad \mathrm{Bi}_{2} \mathrm{Se}_{3}$ and $880 \mathrm{~K}$ [17], or $61 \mathrm{~mol} \% \mathrm{Bi}_{2} \mathrm{Se}_{3}$ and $893 \mathrm{~K}$ [18], or $65 \mathrm{~mol} \% \mathrm{Bi}_{2} \mathrm{Se}_{3}$ and $900 \mathrm{~K}$ [19]. Only very narrow homogeneity regions of the binary compounds were found in the system.

\section{Experimental}

The phase equilibria in the quasi-ternary system $\mathrm{HgSe}-\mathrm{Ga}_{2} \mathrm{Se}_{3}-\mathrm{Bi}_{2} \mathrm{Se}_{3}$ were investigated on alloys located at the boundary side $\mathrm{HgSe}-\mathrm{Bi}_{2} \mathrm{Se}_{3}$ and in four internal sections; additional alloys were synthesized to ascertain the position of the invariant eutectic point (Table 1). Phase and chemical compositions of the alloys are shown in Fig. 1.

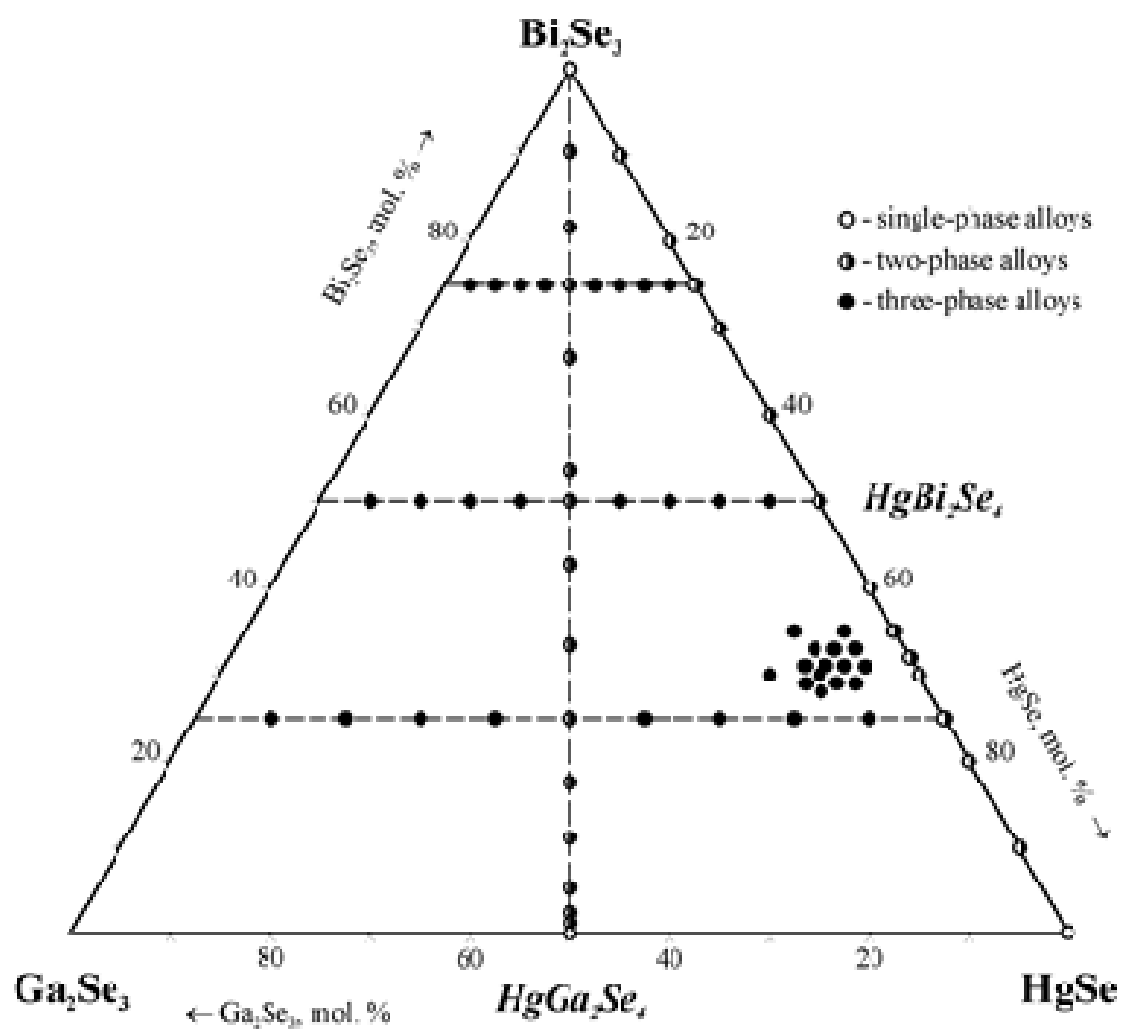

Fig. 1 Composition of the investigated alloys of the $\mathrm{HgSe}-\mathrm{Ga}_{2} \mathrm{Se}_{3}-\mathrm{Bi}_{2} \mathrm{Se}_{3}$ system. 
The alloys were synthesized from high-purity elements (at least 99.99 wt.\% of the principal element) and previously synthesized HgSe. Appropriate amounts of the raw materials were placed in quartz ampoules that were evacuated to a residual pressure of $10^{-2} \mathrm{~Pa}$ and soldered. The synthesis was performed in a shaft-type furnace. The temperature was raised to $1000 \mathrm{~K}$ at the rate of $50 \mathrm{~K} / \mathrm{h}$, kept for $5 \mathrm{~h}$, and increased to $1200 \mathrm{~K}$ at the rate of $15-20 \mathrm{~K} / \mathrm{h}$. After exposure at the maximum temperature for $6 \mathrm{~h}$, the alloys were slowly cooled at the rate of $30 \mathrm{~K} / \mathrm{h}$ to $670 \mathrm{~K}$ or $520 \mathrm{~K}$. Homogenizing annealing was carried out for $250 \mathrm{~h}$, followed by quenching into cold water. The synthesis resulted in compact dark-gray ingots.

The obtained alloys were investigated by differential thermal analysis (Paulik-Paulik-Erdey derivatograph, Pt/Pt-Rh thermocouple) and X-ray diffraction (XRD; DRON 4-13 diffractometer, $\mathrm{CuK}_{\alpha}$ radiation, Ni-filter, $\theta / 2 \theta$ scan in the angle range $10^{\circ}-70^{\circ}$, scan step $0.05^{\circ}$, exposure time $1 \mathrm{~s}$ ).

\section{Results and discussion}

\section{Triangulation}

Triangulation of the $\mathrm{HgSe}-\mathrm{Ga}_{2} \mathrm{Se}_{3}-\mathrm{Bi}_{2} \mathrm{Se}_{3}$ system was performed based on the results of XRD of the alloys annealed at $670 \mathrm{~K}$ (Fig. 2).

The $\mathrm{HgGa}_{2} \mathrm{Se}_{4}-\mathrm{Bi}_{2} \mathrm{Se}_{3}$ section is quasi-binary at this temperature and separates the system into two sub-systems, $\mathrm{HgSe}-\mathrm{HgGa}_{2} \mathrm{Se}_{4}-\mathrm{Bi}_{2} \mathrm{Se}_{3}$ and $\mathrm{HgGa}_{2} \mathrm{Se}_{4}-$ $\mathrm{Ga}_{2} \mathrm{Se}_{3}-\mathrm{Bi}_{2} \mathrm{Se}_{3}$. The section is non-quasi-binary above the solidus because the ternary compound $\mathrm{HgGa}_{2} \mathrm{Se}_{4}$ melts incongruently.

The system components $\mathrm{HgSe}$ and $\mathrm{Ga}_{2} \mathrm{Se}_{3}$ have solid solution ranges that are stretched along the quasi-binary section $\mathrm{HgSe}-\mathrm{Ga}_{2} \mathrm{Se}_{3}$.

Five alloys of the $\mathrm{Hg}_{5} \mathrm{Ga}_{2} \mathrm{Se}_{8}-\mathrm{Bi}_{2} \mathrm{Se}_{3}$ section were investigated to determine the solid solubility of the $\mathrm{Hg}_{5} \mathrm{Ga}_{2} \mathrm{Se}_{8}$ compound ( $\gamma^{\prime}$-solid solutions). This compound forms by a solid-state reaction of ordering of the $\gamma$-solid solutions of HgSe below $\sim 640 \mathrm{~K}$. The studied alloys were annealed at $520 \mathrm{~K}$, which is below the temperature of formation of $\mathrm{Hg}_{5} \mathrm{Ga}_{2} \mathrm{Se}_{8}$. All the samples were two-phase, i.e. the solid solubility based on $\mathrm{Hg}_{5} \mathrm{Ga}_{2} \mathrm{Se}_{8}$ does not exceed $1 \mathrm{~mol} \%$. The most likely picture of the isothermal section of the $\mathrm{HgSe}-$ $\mathrm{Ga}_{2} \mathrm{Se}_{3}-\mathrm{Bi}_{2} \mathrm{Se}_{3}$ system at $520 \mathrm{~K}$ in the region of the existence of the ordered phase is presented in Fig. 3.

\section{The $\mathrm{HgSe}-\mathrm{Bi}_{2} \mathrm{Se}_{3}$ system}

The $\mathrm{HgSe}-\mathrm{Bi}_{2} \mathrm{Se}_{3}$ system is a boundary side of the quasi-ternary system $\mathrm{HgSe}-\mathrm{Ga}_{2} \mathrm{Se}_{3}-\mathrm{Bi}_{2} \mathrm{Se}_{3}$. The phase diagram of this system is of the eutectic type with an incongruently melting compound (Fig. 4). The system liquidus consists of the curves of primary crystallization of $\mathrm{HgSe}, \mathrm{Bi}_{2} \mathrm{Se}_{3}$ and $\mathrm{HgBi}_{2} \mathrm{Se}_{4}$. The endothermal compound $\mathrm{HgBi}_{2} \mathrm{Se}_{4}$, which exists in the temperature range $908-848 \mathrm{~K}$, forms by the peritectic reaction $\mathrm{L}+\mathrm{Bi}_{2} \mathrm{Se}_{3} \leftrightarrows \mathrm{HgBi}_{2} \mathrm{Se}_{4}$ at $908 \mathrm{~K}$. The eutectic reaction $\mathrm{L} \leftrightarrows \mathrm{HgSe}+\mathrm{HgBi}_{2} \mathrm{Se}_{4}$ takes place at $870 \mathrm{~K}$; the composition coordinate of the eutectic point is $32 \mathrm{~mol} \% \mathrm{Bi}_{2} \mathrm{Se}_{3}$.

Typical DTA curves of the alloys of the HgSe$\mathrm{Bi}_{2} \mathrm{Se}_{3}$ system (heating effects) are plotted in Fig. 5 . Typical XRD patterns of the samples of the HgSe$\mathrm{Bi}_{2} \mathrm{Se}_{3}$ system are presented in Fig. 6.

\section{The $\mathrm{HgGa}_{2} \mathrm{Se}_{4}-\mathrm{Bi}_{2} \mathrm{Se}_{3}$ section}

The vertical section $\mathrm{HgGa}_{2} \mathrm{Se}_{4}-\mathrm{Bi}_{2} \mathrm{Se}_{3}$ was investigated by DTA and XRD (Fig. 7). The aim was to determine the flow of the monovariant line $e_{1} U_{3}$ (see Fig. 11) and the boundaries of the invariant peritectic processes in the system. The section liquidus is represented by the curves of primary crystallization of the solid solution ranges of $\mathrm{Ga}_{2} \mathrm{Se}_{3}$ and $\mathrm{Bi}_{2} \mathrm{Se}_{3}$. At $898 \mathrm{~K}$ the section crosses the plane of the invariant peritectic process $\mathrm{L}_{\mathrm{U} 1}+\mathrm{HT}-\mathrm{HgGa}_{2} \mathrm{Se}_{4} \leftrightarrows$ $\mathrm{LT}-\mathrm{HgGa}_{2} \mathrm{Se}_{4}+\mathrm{Ga}_{2} \mathrm{Se}_{3}$, forming a horizontal line to which the region of the coexistence of three phases, $\mathrm{L}+\mathrm{HT}-\mathrm{HgGa} \mathrm{Se}_{4}+\mathrm{Ga}_{2} \mathrm{Se}_{3}$, converges.

Below this horizontal line there is a region of the monovariant eutectic process $\mathrm{L} \leftrightarrows \mathrm{LT}-\mathrm{HgGa}_{2} \mathrm{Se}_{4}+$ $\mathrm{Ga}_{2} \mathrm{Se}_{3}$. This, together with the region of the monovariant eutectic process $\mathrm{L} \leftrightarrows \mathrm{Ga}_{2} \mathrm{Se}_{3}+$ $\mathrm{Bi}_{2} \mathrm{Se}_{3}$, converge to the horizontal line that belongs to the plane of another invariant peritectic process $\mathrm{L}_{\mathrm{U} 1}+\mathrm{Ga}_{2} \mathrm{Se}_{3} \leftrightarrows \mathrm{LT}-\mathrm{HgGa}_{2} \mathrm{Se}_{4}+\mathrm{Bi}_{2} \mathrm{Se}_{3}$, which takes place at $888 \mathrm{~K}$. The horizontal line at $888 \mathrm{~K}$ coincides with the connecting line of the plane of the invariant peritectic process $\mathrm{L}_{\mathrm{U} 2}+\mathrm{Ga}_{2} \mathrm{Se}_{3} \leftrightarrows$ $\mathrm{LT}-\mathrm{HgGa}_{2} \mathrm{Se}_{4}+\mathrm{Bi}_{2} \mathrm{Se}_{3}$. Therefore, the alloys of this section are two-phase below $888 \mathrm{~K}$ (LT-HgGa $\mathrm{Se}_{4}+\mathrm{Bi}_{2} \mathrm{Se}_{3}$ ).

The solid solubility of the system components is negligible, as indicated by the virtually absent shift of the reflections in the diffraction patterns of the alloys.

Table 1 Composition of the invariant points in the quasi-ternary $\mathrm{HgSe}-\mathrm{Ga}_{2} \mathrm{Se}_{3}-\mathrm{Bi}_{2} \mathrm{Se}_{3}$ system.

\begin{tabular}{cccc}
\hline \multirow{2}{*}{ Invariant point } & \multicolumn{3}{c}{ Composition, mol.\% } \\
\cline { 2 - 4 } & $\mathrm{HgSe}$ & $\mathrm{Ga}_{2} \mathrm{Se}_{3}$ & $\mathrm{Bi}_{2} \mathrm{Se}_{3}$ \\
\hline $\mathrm{U}_{1}$ & 34 & 22 & 44 \\
$\mathrm{U}_{2}$ & 68 & 10 & 22 \\
$\mathrm{U}_{3}$ & 33 & 21 & 46 \\
$\mathrm{U}_{4}$ & 52 & 11 & 37 \\
$\mathrm{E}$ & 63 & 7 & 30 \\
\hline
\end{tabular}




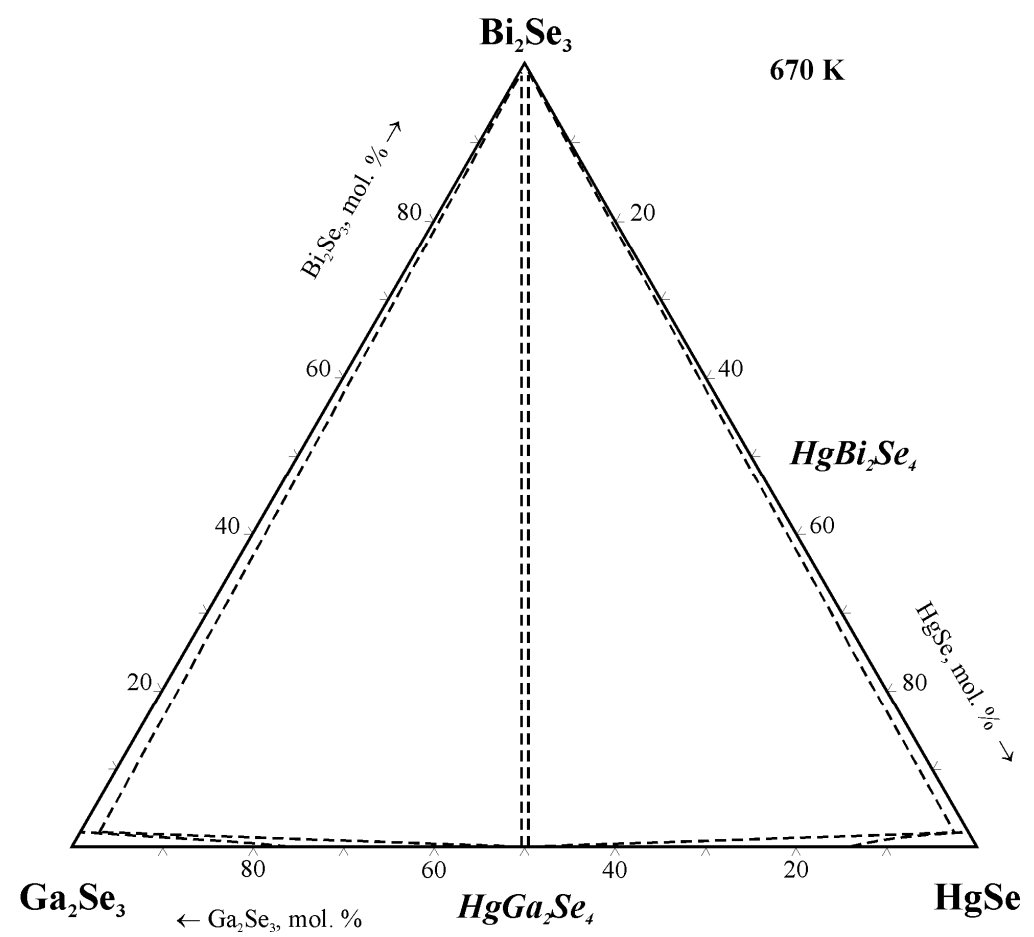

Fig. 2 Isothermal section of the $\mathrm{HgSe}-\mathrm{Ga}_{2} \mathrm{Se}_{3}-\mathrm{Bi}_{2} \mathrm{Se}_{3}$ system at $670 \mathrm{~K}$

\section{K}

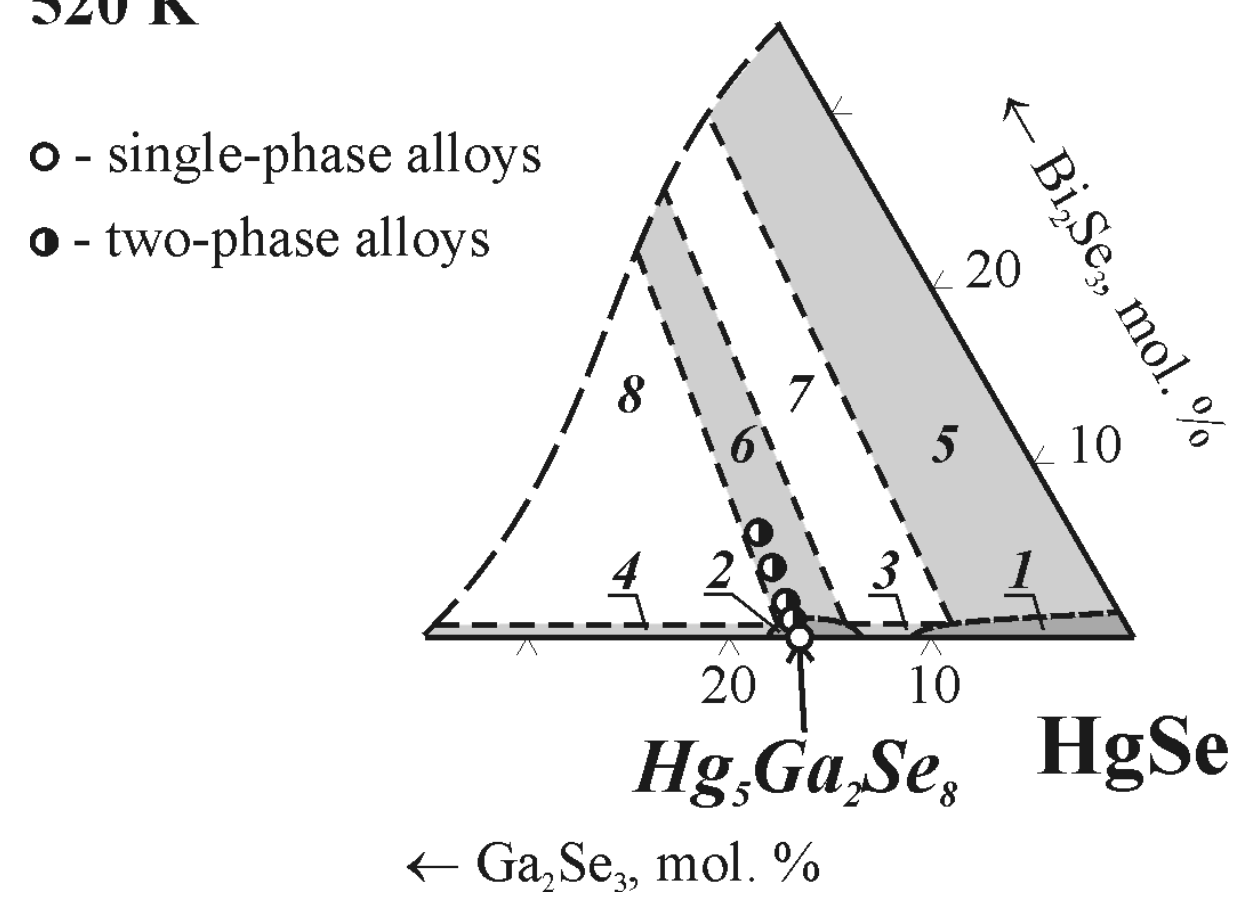

Fig. 3 Isothermal section of the $\mathrm{HgSe}-\mathrm{Ga}_{2} \mathrm{Se}_{3}-\mathrm{Bi}_{2} \mathrm{Se}_{3}$ system at $520 \mathrm{~K}$ in the region of existence of the $\mathrm{Hg}_{5} \mathrm{Ga}_{2} \mathrm{Se}_{8}$ phase, including phase and chemical composition of the alloys: $\boldsymbol{1}-\gamma ; 2-\gamma^{\prime} ; \mathbf{3}-\gamma+\gamma^{\prime}$; $4-\mathrm{LT}-\mathrm{HgGa}_{2} \mathrm{Se}_{4}+\gamma^{\prime} ; \mathbf{5}-\gamma+\mathrm{Bi}_{2} \mathrm{Se}_{3} ; \boldsymbol{\sigma}-\gamma^{\prime}+\mathrm{Bi}_{2} \mathrm{Se}_{3} ; 7-\gamma+\gamma^{\prime}+\mathrm{Bi}_{2} \mathrm{Se}_{3} ; \boldsymbol{8}-\mathrm{LT}-\mathrm{HgGa}_{2} \mathrm{Se}_{4}+\gamma^{\prime}+\mathrm{Bi}_{2} \mathrm{Se}_{3}$. 


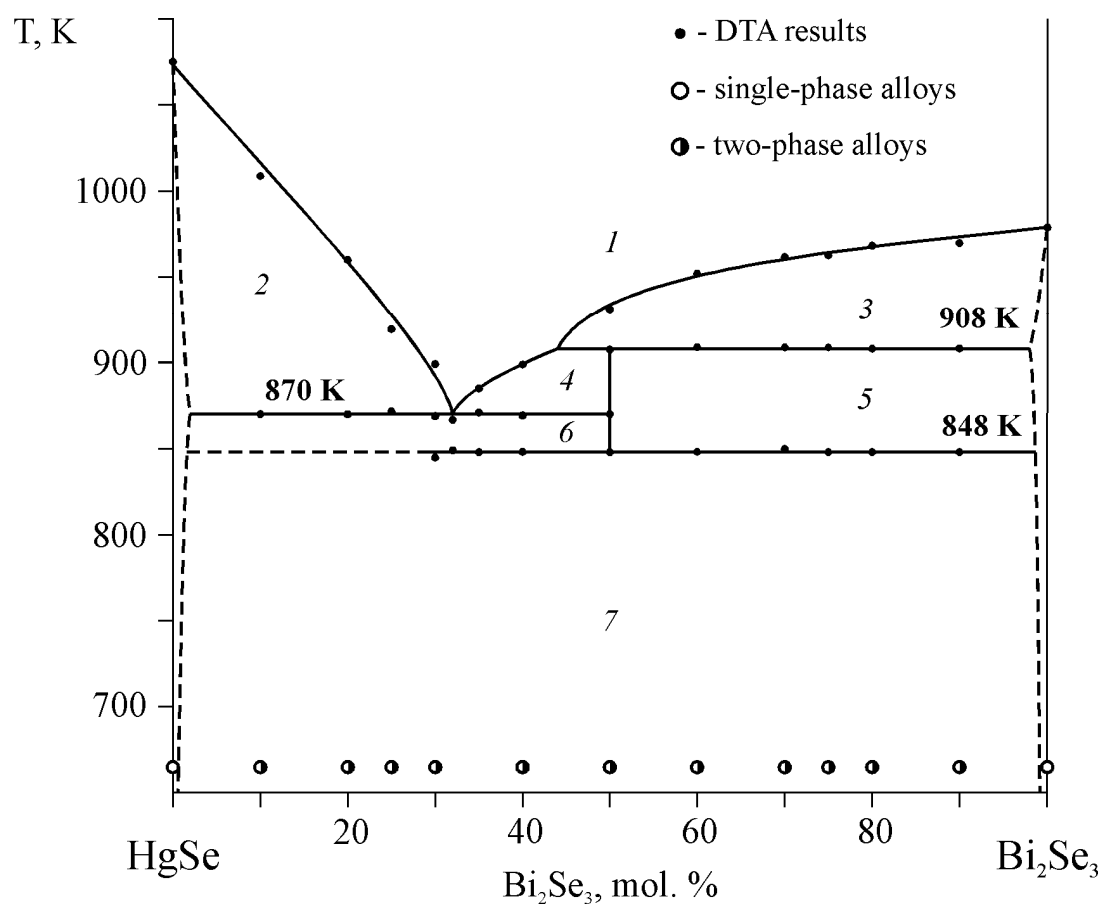

Fig. 4 Phase diagram of the $\mathrm{HgSe}-\mathrm{Bi}_{2} \mathrm{Se}_{3}$ system: $1-\mathrm{L} ; 2-\mathrm{L}+\mathrm{HgSe} ; 3-\mathrm{L}+\mathrm{Bi}_{2} \mathrm{Se}_{3} ; 4-\mathrm{L}+\mathrm{HgBi}_{2} \mathrm{Se}_{4}$; $5-\mathrm{HgBi}_{2} \mathrm{Se}_{4}+\mathrm{Bi}_{2} \mathrm{Se}_{3} ; \boldsymbol{6}-\mathrm{HgSe}_{+} \mathrm{HgBi}_{2} \mathrm{Se}_{4} ; 7-\mathrm{HgSe}_{+}+\mathrm{Bi}_{2} \mathrm{Se}_{3}$.

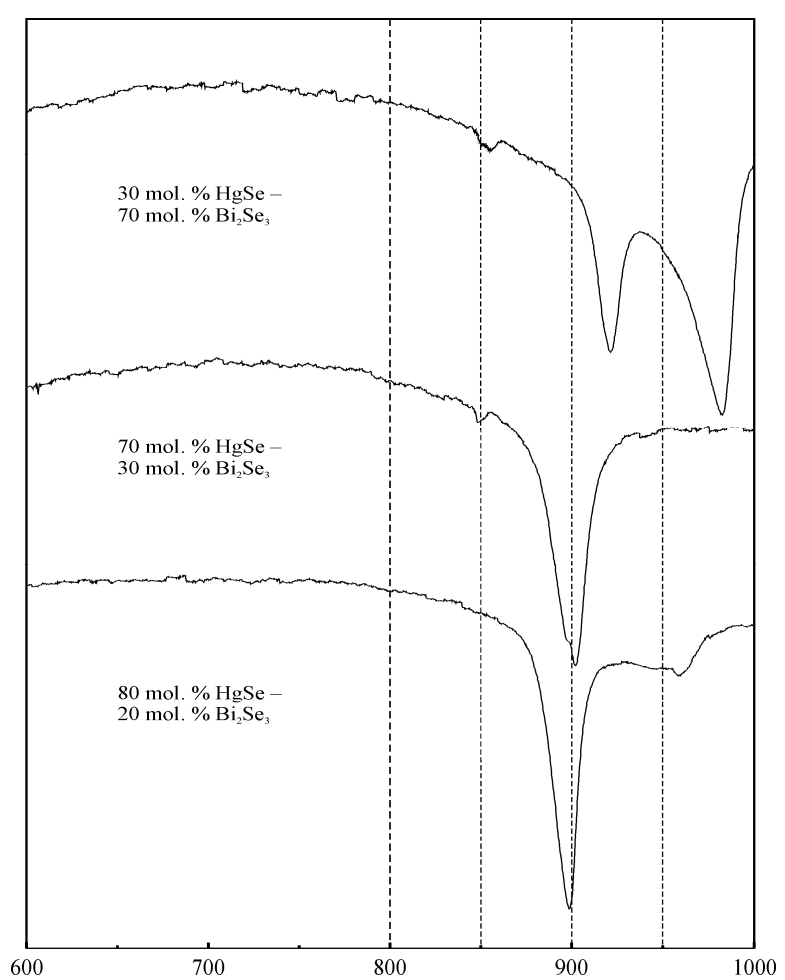

Fig. 5 Typical DTA curves of alloys of the $\mathrm{HgSe}-\mathrm{Bi}_{2} \mathrm{Se}_{3}$ system (heating effects).

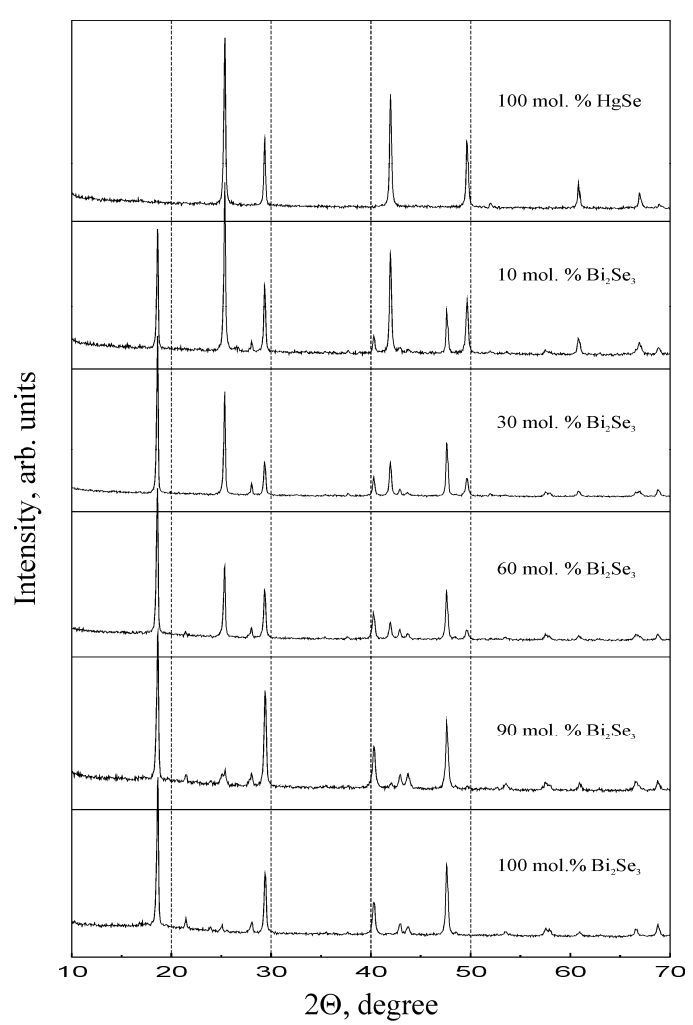

Fig. 6 Typical XRD patterns of alloys of the $\mathrm{HgSe}-\mathrm{Bi}_{2} \mathrm{Se}_{3}$ system. 


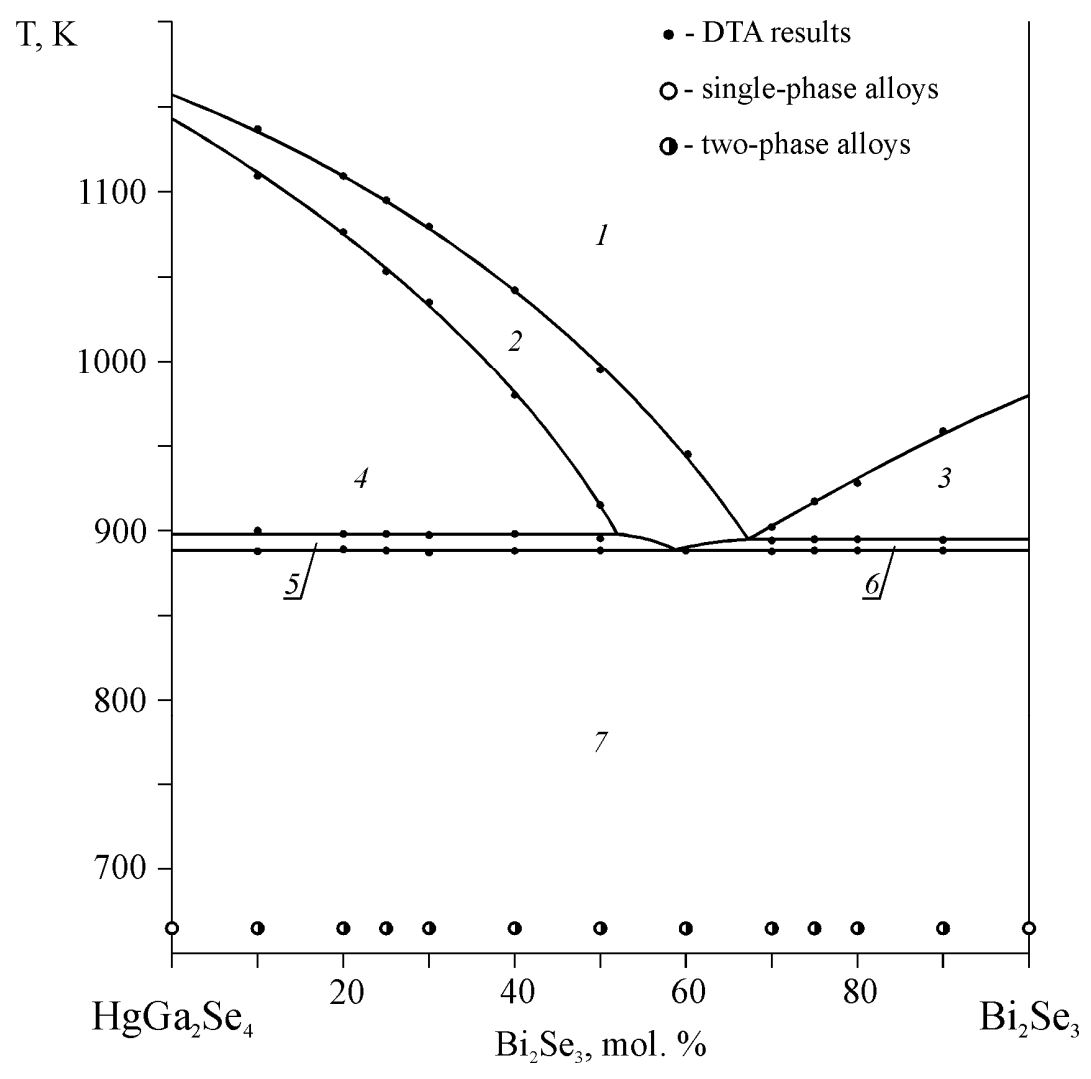

Fig. 7 Vertical section $\mathrm{HgGa}_{2} \mathrm{Se}_{4}-\mathrm{Bi}_{2} \mathrm{Se}_{3}: 1-\mathrm{L} ; 2-\mathrm{L}+\mathrm{Ga}_{2} \mathrm{Se}_{3} ; 3-\mathrm{L}+\mathrm{Bi}_{2} \mathrm{Se}_{3} ; 4-\mathrm{L}+\mathrm{HT}-\mathrm{HgGa}_{2} \mathrm{Se}_{4}+\mathrm{Ga}_{2} \mathrm{Se}_{3}$; $5-\mathrm{L}+\mathrm{Ga}_{2} \mathrm{Se}_{3}+\mathrm{LT}-\mathrm{HgGa}_{2} \mathrm{Se}_{4} ; \boldsymbol{\sigma}-\mathrm{L}+\mathrm{Ga}_{2} \mathrm{Se}_{3}+\mathrm{Bi}_{2} \mathrm{Se}_{3} ; 7-\mathrm{LT}-\mathrm{HgGa}_{2} \mathrm{Se}_{4}+\mathrm{Bi}_{2} \mathrm{Se}_{3}$.

Sections ' $\mathrm{Ga}_{1.5} \mathrm{Bi}_{0.5} \mathrm{Se}_{3}$ '-' $\mathrm{HgBi}_{0.5} \mathrm{Se}_{1.5}$ ', 2' ${ }^{\prime} \mathrm{GaBiSe}_{3}$ '$\mathrm{HgBi}_{2} \mathrm{Se}_{4}$ and ' $\mathrm{Ga}_{0.5} \mathrm{Bi}_{1.5} \mathrm{Se}_{3}$ '-' $\mathrm{Hg}_{0.25} \mathrm{Bi}_{1.5} \mathrm{Se}_{2.5}$ ' Vertical sections ' $\mathrm{Ga}_{1.5} \mathrm{Bi}_{0.5} \mathrm{Se}_{3}{ }^{\prime}-{ }^{\prime} \mathrm{HgBi}_{0.5} \mathrm{Se}_{1.5}$ ' (Fig. 8), 2' $\mathrm{GaBiSe}_{3}{ }^{\prime}-\mathrm{HgBi}_{2} \mathrm{Se}_{4}$ (Fig. 9) and ' $\mathrm{Ga}_{0.5} \mathrm{Bi}_{1.5} \mathrm{Se}_{3}{ }^{\prime}-{ }^{\prime} \mathrm{Hg}_{0.25} \mathrm{Bi}_{1.5} \mathrm{Se}_{2.5}$ ' (Fig. 10) were plotted bases on DTA and XRD. These sections were studied to determine the location of the monovariant lines, and the boundaries of the invariant processes that take place in the system.

The ' $\mathrm{Ga}_{1.5} \mathrm{Bi}_{0.5} \mathrm{Se}_{3}{ }^{\prime}-{ }^{\prime} \mathrm{HgBi}_{0.5} \mathrm{Se}_{1.5}$ ' section (Fig. 8) coincides with the concentration line $25 \mathrm{~mol} . \%$ $\mathrm{Bi}_{2} \mathrm{Se}_{3}$. It crosses four regions of primary crystallization, those of the solid solution ranges of $\mathrm{Ga}_{2} \mathrm{Se}_{3}, \mathrm{HT}-\mathrm{HgGa}_{2} \mathrm{Se}_{4}$, LT-HgGa $\mathrm{Se}_{4}$, and $\mathrm{HgSe}$. Below the liquidus line, in addition to the fields of primary crystallization, the section crosses seven volumes of secondary crystallization. The solidus is represented by the lines of completion of secondary crystallization of the binary eutectics and three horizontal lines of the invariant processes $\mathrm{L}_{\mathrm{U} 3}+\mathrm{Ga}_{2} \mathrm{Se}_{3} \leftrightarrows \mathrm{LT}-\mathrm{HgGa}_{2} \mathrm{Se}_{4}+\mathrm{Bi}_{2} \mathrm{Se}_{3}$ at $888 \mathrm{~K}$, $\mathrm{L}_{\mathrm{U}}+\mathrm{Bi}_{2} \mathrm{Se}_{3} \leftrightarrows \mathrm{LT}-\mathrm{HgGa}_{2} \mathrm{Se}_{4}+\mathrm{HgBi}_{2} \mathrm{Se}_{4}$ at $870 \mathrm{~K}$, and $\mathrm{L}_{\mathrm{E}} \leftrightarrows \mathrm{LT}-\mathrm{HgGa}_{2} \mathrm{Se}_{4}+\mathrm{Ga}_{2} \mathrm{Se}_{3}+\mathrm{HgBi}_{2} \mathrm{Se}_{4}+\mathrm{HgSe}$ at $863 \mathrm{~K}$. Two other horizontal lines at $898 \mathrm{~K}$ and $840 \mathrm{~K}$ belong to the plane of the polymorphous transition of the ternary phase $\mathrm{HgGa}_{2} \mathrm{Se}_{4}$ and the plane of the decomposition of the endothermal compound $\mathrm{HgBi}_{2} \mathrm{Se}_{4}$. All the investigated alloys were three-phase at the annealing temperature, except the alloys containing 0,50 and $100 \mathrm{~mol} . \%$ ' $\mathrm{HgBi}_{0.5} \mathrm{Se}_{1.5}$ '.

The ${ }^{\prime}{ }^{\prime} \mathrm{GaBiSe}_{3}$ '- $\mathrm{HgBi}_{2} \mathrm{Se}_{4}$ section (Fig. 9), which coincides with the concentration line $50 \mathrm{~mol} \%$ $\mathrm{Bi}_{2} \mathrm{Se}_{3}$, crosses the fields of primary crystallization of the solid solution ranges of $\mathrm{Ga}_{2} \mathrm{Se}_{3}$ and $\mathrm{Bi}_{2} \mathrm{Se}_{3}$. Below the liquidus line, in addition to the fields of primary crystallization, the section crosses three volumes of secondary crystallization. The solidus is represented by the lines of the completion of the secondary crystallization of the binary eutectics, and two horizontal lines of the invariant processes $\mathrm{L}_{\mathrm{U} 3}+\mathrm{Ga}_{2} \mathrm{Se}_{3} \leftrightarrows \mathrm{LT}-\mathrm{HgGa}_{2} \mathrm{Se}_{4}+\mathrm{Bi}_{2} \mathrm{Se}_{3}$ at $888 \mathrm{~K}$ and $\mathrm{L}_{\mathrm{U} 4}+\mathrm{Bi}_{2} \mathrm{Se}_{3} \leftrightarrows \mathrm{LT}-\mathrm{HgGa}_{2} \mathrm{Se}_{4}+\mathrm{HgBi}_{2} \mathrm{Se}_{4}$ at $870 \mathrm{~K}$. Another horizontal line at $840 \mathrm{~K}$ belongs to the plane of the decomposition of the endothermal compound $\mathrm{HgBi}_{2} \mathrm{Se}_{4}$. The sub-solidus part is similar to that of the ' $\mathrm{Ga}_{1.5} \mathrm{Bi}_{0.5} \mathrm{Se}_{3}$ '-' $\mathrm{HgBi}_{0.5} \mathrm{Se}_{1.5}$ ' section (Fig. 8).

The ' $\mathrm{Ga}_{0.5} \mathrm{Bi}_{1.5} \mathrm{Se}_{3}$ '- $\mathrm{Hg}_{0.25} \mathrm{Bi}_{1.5} \mathrm{Se}_{2.5}$ ' section (Fig. 10), which coincides with the concentration line 75 mol. $\% \mathrm{Bi}_{2} \mathrm{Se}_{3}$, crosses only the field of primary crystallization of $\mathrm{Bi}_{2} \mathrm{Se}_{3}$. Otherwise its structure is similar to that of the $2{ }^{\prime} \mathrm{GaBiSe}_{3}{ }^{\prime}-\mathrm{HgBi}_{2} \mathrm{Se}_{4}$ section (Fig. 9). 


\section{Liquidus surface projection of the quasi-ternary system $\mathrm{HgSe}-\mathrm{Ga}_{2} \mathrm{Se}_{3}-\mathrm{Bi}_{2} \mathrm{Se}_{3}$}

The projection of the liquidus surface of the $\mathrm{HgSe}-$ $\mathrm{Ga}_{2} \mathrm{Se}_{3}-\mathrm{Bi}_{2} \mathrm{Se}_{3}$ system onto the concentration triangle (Fig. 11) was constructed from literature data on the phase diagrams of the $\mathrm{HgSe}-\mathrm{Ga}_{2} \mathrm{~S}_{3}$ and $\mathrm{Ga}_{2} \mathrm{~S}_{3}-\mathrm{Bi}_{2} \mathrm{~S}_{3}$ systems, and our own results on the boundary side $\mathrm{HgSe}-\mathrm{Bi}_{2} \mathrm{~S}_{3}$ and the four vertical sections described above.

The liquidus surface consists of six fields of primary crystallization belonging to the solid solution ranges of the system components $\mathrm{HgSe}, \mathrm{Ga}_{2} \mathrm{Se}_{3}$ and $\mathrm{Bi}_{2} \mathrm{Se}_{3}$, and the ternary compounds $\mathrm{HT}-\mathrm{HgGa} \mathrm{Se}_{4}$,
LT- $\mathrm{HgGa}_{2} \mathrm{Se}_{4}$ and $\mathrm{HgBi}_{2} \mathrm{Se}_{4}$. The fields of primary crystallization are separated by ten monovariant lines and ten invariant points, of which five are ternary (four ternary peritectics and one ternary eutectic) and five are binary points (two binary eutectics and three binary peritectics). The composition of the ternary invariant points was determined geometrically using the data on the phase equilibria of the vertical sections.

The type and temperature of the monoand invariant processes in the quasi-ternary system $\mathrm{HgSe}-\mathrm{Ga}_{2} \mathrm{Se}_{3}-\mathrm{Bi}_{2} \mathrm{Se}_{3}$ are summarized in Fig. 12.

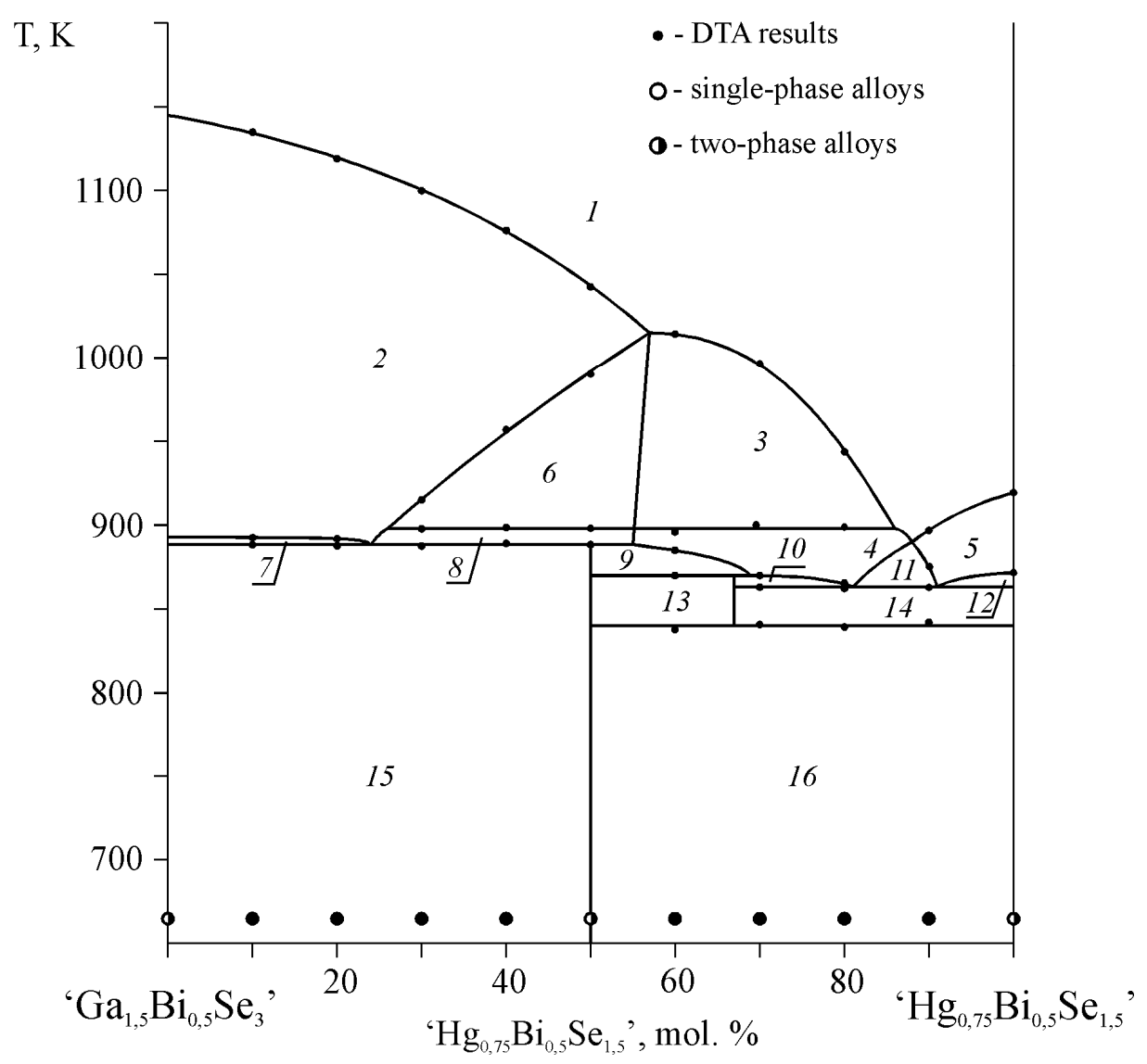

Fig. 8 Vertical section ' $\mathrm{Ga}_{1,5} \mathrm{Bi}_{0,5} \mathrm{Se}_{3}$ '- $\mathrm{HgBi}_{0,5} \mathrm{Se}_{1,5}$ ': $\mathbf{1}-\mathrm{L} ; \quad \boldsymbol{2}-\mathrm{L}+\mathrm{Ga}_{2} \mathrm{Se}_{3} ; \quad 3-\mathrm{L}+\mathrm{HT}-\mathrm{HgGa}_{2} \mathrm{Se}_{4}$; 4- $-\mathrm{L}+\mathrm{LT}-\mathrm{HgGa}_{2} \mathrm{Se}_{4} ; \quad \mathbf{5}-\mathrm{L}+\mathrm{HgSe} ; \quad \boldsymbol{6}-\mathrm{L}+\mathrm{HT}-\mathrm{HgGa}_{2} \mathrm{Se}_{4}+\mathrm{Ga}_{2} \mathrm{Se}_{3} ; \quad 7-\mathrm{L}_{+} \mathrm{Ga}_{2} \mathrm{Se}_{3}+\mathrm{Bi}_{2} \mathrm{Se}_{3}$; $\boldsymbol{8}-\mathrm{L}+\mathrm{LT}-\mathrm{HgGa}_{2} \mathrm{Se}_{4}+\mathrm{Ga}_{2} \mathrm{Se}_{3} ; \quad 9-\mathrm{L}+\mathrm{LT}-\mathrm{HgGa}_{2} \mathrm{Se}_{4}+\mathrm{Bi}_{2} \mathrm{Se}_{3} ; \quad \mathbf{1 0}-\mathrm{L}+\mathrm{LT}-\mathrm{HgGa}_{2} \mathrm{Se}_{4}+\mathrm{HgBi}_{2} \mathrm{Se}_{4}$ $11-\mathrm{L}+\mathrm{LT}-\mathrm{HgGa} \mathrm{Se}_{4}+\mathrm{HgSe} ; \quad 12-\mathrm{L}+\mathrm{HgSe}+\mathrm{HgBi}_{2} \mathrm{Se}_{4} ; \quad 13-\mathrm{Bi}_{2} \mathrm{Se}_{3}+\mathrm{LT}-\mathrm{HgGa}_{2} \mathrm{Se}_{4}+\mathrm{HgBi}_{2} \mathrm{Se}_{4} ;$ $14-\mathrm{HgSe}+\mathrm{LT}-\mathrm{HgGa}_{2} \mathrm{Se}_{4}+\mathrm{HgBi}_{2} \mathrm{Se}_{4} ; 15-\mathrm{LT}-\mathrm{HgGa}_{2} \mathrm{Se}_{4}+\mathrm{Ga}_{2} \mathrm{Se}_{3}+\mathrm{Bi}_{2} \mathrm{Se}_{3} ; 16-\mathrm{LT}-\mathrm{HgGa}_{2} \mathrm{Se}_{4}+\mathrm{Bi}_{2} \mathrm{Se}_{3}+\mathrm{HgSe}$ 


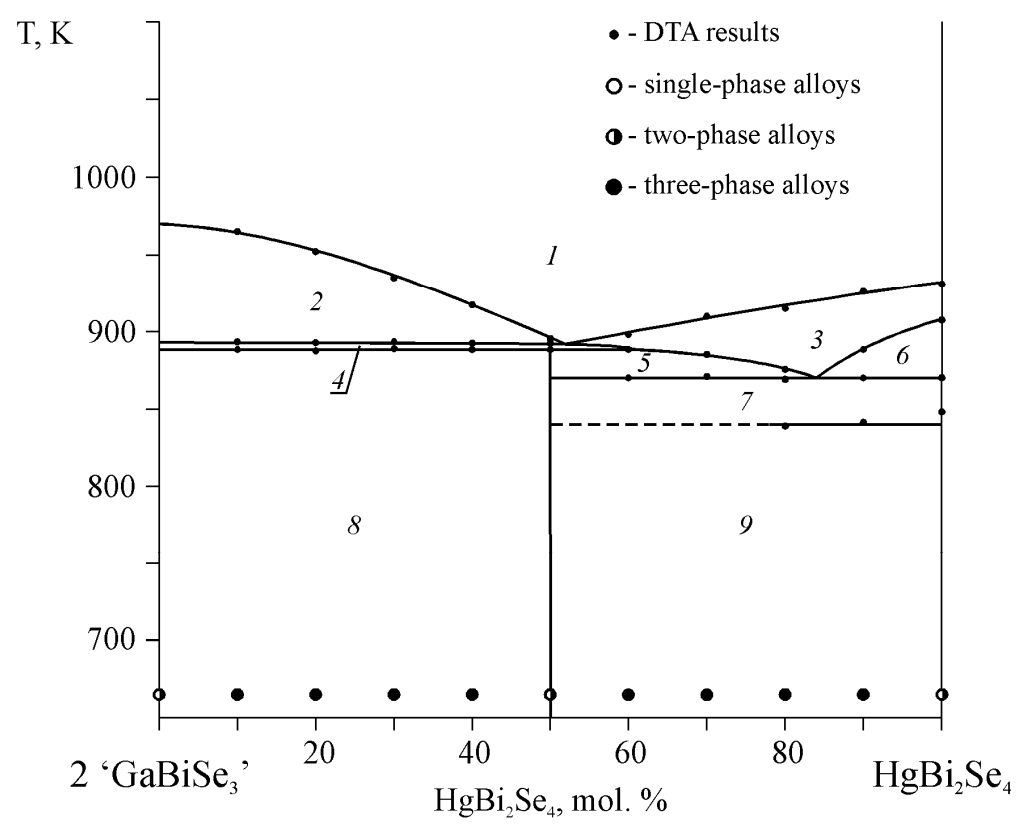

Fig. 9 Vertical section 2 ' $\mathrm{GaBiSe}{ }_{3}-\mathrm{HgBi}_{2} \mathrm{Se}_{4}$ : $1-\mathrm{L} ; 2-\mathrm{L}+\mathrm{Ga}_{2} \mathrm{Se}_{3} ; 3-\mathrm{L}+\mathrm{Bi}_{2} \mathrm{Se}_{3} ; 4-\mathrm{L}+\mathrm{Ga}_{2} \mathrm{Se}_{3}+\mathrm{Bi}_{2} \mathrm{Se}_{3}$; $5-\mathrm{L}+\mathrm{LT}-\mathrm{HgGa}_{2} \mathrm{Se}_{4}+\mathrm{Bi}_{2} \mathrm{Se}_{3} ; \quad \boldsymbol{6}-\mathrm{L}_{+} \mathrm{Bi}_{2} \mathrm{Se}_{3}+\mathrm{HgBi}_{2} \mathrm{Se}_{4}$; $\boldsymbol{8}-\mathrm{Ga}_{2} \mathrm{Se}_{3}+\mathrm{Bi}_{2} \mathrm{Se}_{3}+\mathrm{LT}-\mathrm{HgGa} \mathrm{Se}_{4} ; \boldsymbol{9}-\mathrm{LT}-\mathrm{HgGa} \mathrm{Se}_{4}+\mathrm{Bi}_{2} \mathrm{Se}_{3}+\mathrm{HgSe}$.

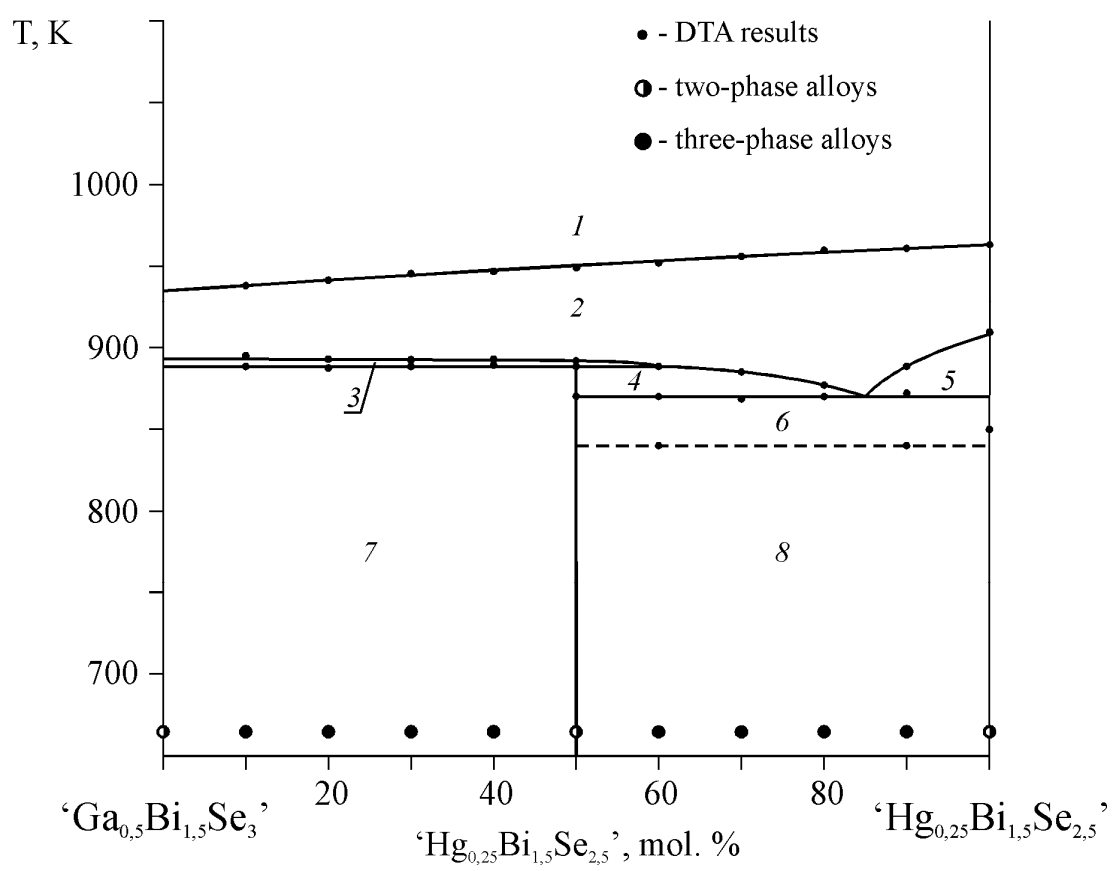

Fig. 10 Vertical section ' $\mathrm{Ga}_{0,5} \mathrm{Bi}_{1,5} \mathrm{Se}_{3}{ }^{\prime}-\mathrm{Hg}_{0,25} \mathrm{Bi}_{1,5} \mathrm{Se}_{2,5}$ ': $\mathbf{1}-\mathrm{L} ; \quad \mathbf{2}-\mathrm{L}+\mathrm{Bi}_{2} \mathrm{Se}_{3} ; \quad \mathbf{3}-\mathrm{L}_{+} \mathrm{Ga}_{2} \mathrm{Se}_{3}+\mathrm{Bi}_{2} \mathrm{Se}_{3}$; $4-\mathrm{L}+\mathrm{LT}-\mathrm{HgGa}_{2} \mathrm{Se}_{4}+\mathrm{Bi}_{2} \mathrm{Se}_{3} ; \quad 5-\mathrm{L}+\mathrm{Bi}_{2} \mathrm{Se}_{3}+\mathrm{HgBi}_{2} \mathrm{Se}_{4}$; 6- $\mathrm{LT}-\mathrm{HgGa}_{2} \mathrm{Se}_{4}+\mathrm{Bi}_{2} \mathrm{Se}_{3}+\mathrm{HgBi}_{2} \mathrm{Se}_{4}$; $7-\mathrm{Ga}_{2} \mathrm{Se}_{3}+\mathrm{Bi}_{2} \mathrm{Se}_{3}+\mathrm{LT}-\mathrm{HgGa} \mathrm{Se}_{4} ; \boldsymbol{8}-\mathrm{LT}-\mathrm{HgGa} \mathrm{Se}_{4}+\mathrm{Bi}_{2} \mathrm{Se}_{3}+\mathrm{HgSe}$. 


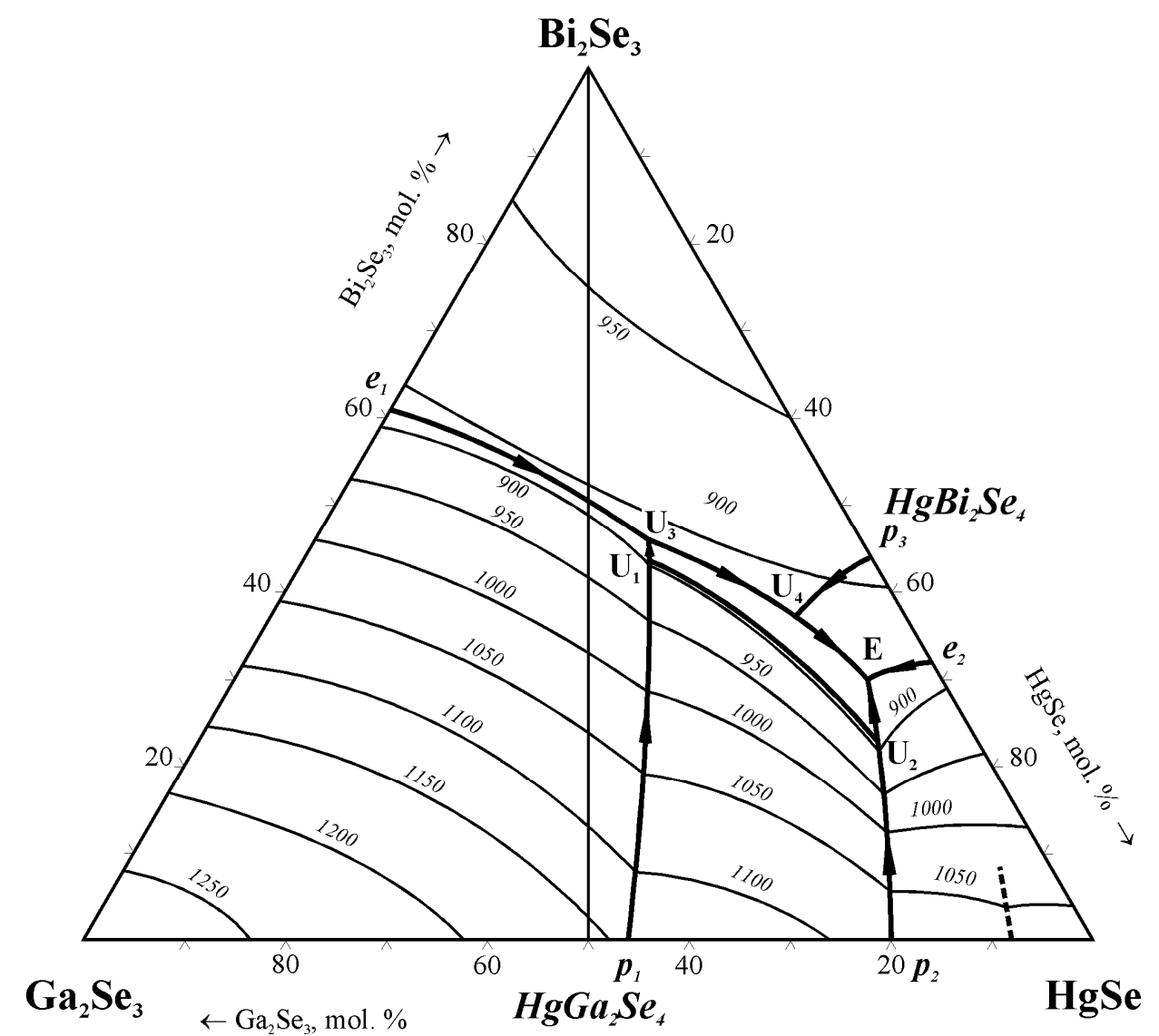

Fig. 11 Liquidus surface projection of the $\mathrm{HgSe}-\mathrm{Ga}_{2} \mathrm{Se}_{3}-\mathrm{Bi}_{2} \mathrm{Se}_{3}$ system.

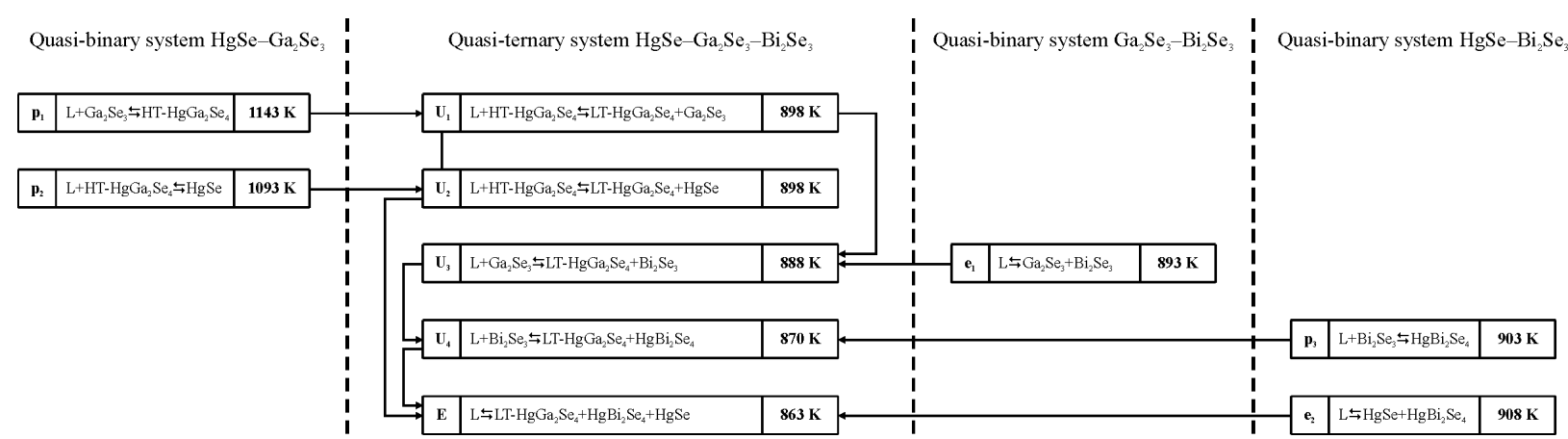

Fig. 12 Liquid-solid equilibria in the $\mathrm{HgSe}-\mathrm{Ga}_{2} \mathrm{Se}_{3}-\mathrm{Bi}_{2} \mathrm{Se}_{3}$ quasi-ternary system.

\section{Conclusions}

The phase equilibria in the quasi-ternary system $\mathrm{HgSe}-\mathrm{Ga}_{2} \mathrm{Se}_{3}-\mathrm{Bi}_{2} \mathrm{Se}_{3}$ were investigated by differential thermal analysis and X-ray diffraction. Five vertical sections and the isothermal section of the system at $670 \mathrm{~K}$ (and partly at $520 \mathrm{~K}$ ) were plotted. Based on these data and literature data on the quasi-binary side systems, the projection of the liquidus surface onto the concentration triangle was constructed. It consists of six fields of primary crystallization. The presence of the field of primary crystallization of $\mathrm{HgGa}_{2} \mathrm{Se}_{4}$ makes it possible to select compositions and conditions for the growth of crystals of this ternary phase by the solution-melt method. 


\section{References}

[1] V.V. Badikov, N.V. Kuzmin, V.B. Laptev, A.L. Malinovsky, K.V. Mitin, G.S. Nazarov, E.A. Ryabov, A.M. Seryogin, N.I. Shchebetova, Quantum Electron. 34 (2004) 451-456.

[2] V.V. Badikov, A.K. Don, K.V. Mitin, A.M. Seregin, V.V. Sinaiskii, N.I. Shchebetova, Quantum Electron. 33 (2003) 831-832.

[3] L.M. Suslikov, V.Yu. Slivka, M.P. Lisitsa, Solid-State Optical Filters on Gyrotropic Crystals, Interpres LTD, Kyiv, 1998 (in Ukrainian).

[4] Y.O. Derid, S.I. Radautsan, I.M. Tiginyanu. Multicomponent Chalcogenides $A^{I I} B^{I I I} C^{V I}$, Stiintsa, Chisineu, 1998 (in Russian).

[5] K.-N. Ding, W. Jia, Y.-F. Zhang, Jiegou Huaxue (Chin. J. Struct. Chem.) 32 (2013) 1307-1315.

[6] R. Sharma, S. Dwivedi, Y. Sharma, Proc. Int. Conf. Condens. Matter \& Appl. Phys. DOI: 10.1063/1.4946191.

[7] Wha-Tek Kim, Gi-Jun Cho, Chang-Sub Kim, Chang-Dae Kim, Phys. Rev. B 43 (1991) 14265.

[8] B.V. Gabrelian, A.A. Lavrentyev, T.V. Vu, O.V. Parasyuk, O.Y. Khyzhun, Opt. Mater. 75 (2018) 538-546.

[9] I.D. Olekseyuk, O.V. Parasyuk, P.S. Salamakha, Yu.M. Prots, J. Alloys Compd. 238 (1996) 141-148.

[10] I.D. Olekseyuk, O.V. Parasyuk, Zh. Neorg. Khim. 42 (1997) 838-842.
[11] I.D. Olekseyuk, O.V. Parasyuk, Proc. 1st Int. Conf. Mater. Sci. Chalcogen and DiamondStructure Semiconductors, Chernivtsi, 1994, vol. 1, p. 111.

[12] O.P. Derid, Investigation of the Phase Diagrams of the Ternary Systems $A^{I I}-B^{I I I}-C^{V I}$, In: Theoretical and Experimental Investigation of Complex Semiconductor Compounds, Stiinza, Chisineu, 1978, p. 44-64 (in Russian).

[13] N.N. Metlinskiy, V.G. Tyrziu, M.M. Markus et al. Phase Diagram of the $\mathrm{HgSe}-\mathrm{Ga}_{2} \mathrm{Se}_{3} \mathrm{System}$, In: Single Crystals and Technology 1(8) (1973) pp. 52-56 (in Russian).

[14] Yu.V. Voroshylov, T.L. Yevstigneyeva, I.Ya. Nekrasov, Crystal Chemical Tables of Ternary Chalcogenides, Nauka, Moscow, 1989 (in Russian).

[15] L. Gastaldi, M.P. Pardo, C. R. Hebd. Seances Acad. Sci. 298 (1984) 37-38.

[16] V.R. Kozer, A.O. Fedorchuk, I.D. Olekseyuk, O.V. Parasyuk, J. Alloys Compd. 503 (2010) 40-43.

[17] P. Villars, A. Prince, H. Okamoto (Eds.), Handbook of Ternary Alloy Phase Diagrams, ASM International, Materials Park, 1995.

[18] R. Eholie, J. Flahaut, Bull. Soc. Chim. Fr. 202 (1972) $1250-1254$.

[19] S.M. Sosovska, O.V. Hurska, L.V. Piskach, O.V. Parasyuk, Nauk. Visn. Volyn. Nats. Univ., Khim. Nauky 4 (2006) 66-70. 